\title{
Analisis Watak Tokoh dalam Novel Sebening Senja Karya Nawank Wulan Kajian Psikologi
}

\author{
Dwi Sistiana \\ Dwixx99@gmail.com
}

STKIP Muhammadiyah Pagar Alam

\begin{abstract}
Abstact: Literary work born caused basic human impulse to express a feeling of the contents of his heart, and his mind, put the interests of human problem and humanity , and the existence of attention to the world the reality of that lasted all day and all the days of. The study psychology, researchers used tipe-tipe nature of the figures in terms of interpersonal needs according to william c. Schutz namely: in terms of ketermasukan; terms of power, both keafektifan. Problems in research is: (1) how psychological analysis in a novel sebening senja work nawank wulan theory personality william c.Shutz .

Methods used in research is a qualitative descriptive with psychological approach to the nature of the novel can be classified properly. Based on the research done it is known that psychological .In a novel sebening senja it has found psychological which includes type or inclusion, type power or control and type keafektifan or affection.
\end{abstract}

Keysword: novel, psychological, humanity

\section{PENDAHULUAN}

$\begin{array}{lllr}\text { Karya } & \text { sastra } & \text { lahir disebabkan } \\ \text { dorongan } & \text { dasar } & \text { manusia untuk }\end{array}$
mengungkapkan isi hatinya, perasaan, dan pikirannya, menaruh minat terhadap masalah manusia dan kemanusiaan, serta adanya perhatian terhadap dunia realitas yang berlangsung sepanjang hari dan sepanjang zaman.

Karya sastra sangat menarik untuk dibaca sebagai hiburan dan karya sastra yang baik juga harus memiliki nilai kemanfaatan berupa pelajaran-pelajaran yang dapat diambil di dalamnya, karena inilah suatu karya sastra juga menarik untuk dikaji atau dianalisis. Dengan mengkaji karya sastra kita dapat memperoleh dua keuntungan dari membaca karya sastra yaitu fungsi hiburan dan fungsi pembelajaran. Selain itu sebagai insan yang berpendidikan dan sebagai seorang guru kegiatan mengkaji sebuah karya sastra dapat membantu kita dalam menilai sebuah karya sastra. Apakah karya sastra itu baik untuk dibaca oleh semua kalangan atau oleh kalangan tertentu saja.

Karya sastra yang lahir ditengahtengah masyarakat merupakan hasil pengungkapan jiwa pengarang tentang kehidupan, peristiwa, serta pengalaman hidup seseorang. dengan demikian, suatu karya sastra tidak pernah berangkat dari kekosongan sosial. Artinya, karya sastra ditulis berdasarkan kehidupan sosial masyarakat tertentu dan menceritakan kebudayaan-kebudayaan yang melatarbelakanginya. Manusia sebagai 
tumpuan sastra selalu terikat dengan gejolak jiwanya.

Peneliti merasa tertarik untuk melakukan penelitian terhadap karya sastra dari segi psikologis. Hal ini mengingat isi karya sastra sangat berkaitan erat dengan kejadian-kejadian di masyarakat. Novel yang lahir ditengah-tengah masyarakat merupakan hasil pengungkapan jiwa pengarang tentang kehidupan, peristiwa, serta pengalaman hidup seseorang.

\section{ACUAN TEORETIK}

\subsection{Pengertian Novel}

Novel sebagai karya fiksi menawarkan sebuah dunia, dunia yang berisi model kehidupan yang ideal, dunia imajenatif yang dibangun melalui berbagai unsur intrinsiknya, seperti peristiwa, plot, tokoh (dan penokohan), latar sudut pandang dan lain- lainnya yang kesemuanya, tentu saja juga bersifat imajinatif.

Novel memiliki ciri-ciri, yaitu novel lebih panjang daripada cerpen dan lebih pendek daripada roman, sifat dan perubahan para pelakunya diceritakan secara panjang lebar, bahan cerita diangkat dari kehidupan masyarakat, penyajian cerita berlandaskan pada alur pokok dan rangkaian dengan beberapa alur panjang, penyajian cerita hanya sebagian dari kehidupan manusia yang dianggap penting, dan penyajian cerita hanya terpusat dalam kehidupan sesaat.

Menurut Kosasih (2012: 60-71) unsur intrinsik novel terdiri atas tema, alur, latar, penokohan, sudut pandang, amanat dan gaya bahasa. Jadi dapat disimpulkan bahwa unsur intrinsik novel terdiri atas tema, alur, latar, penokohan, sudut pandang, amanat dan gaya bahas

\subsection{Pengertian Psikologis}

Psikologis sastra memberikan perhatian pada masalah yang berkaitan dengan unsur-unsur kejiwaan tokoh-tokoh fiksional yang terkandung dalam sastra tersebut. Aspek-aspek kemanusiaan inilah yang merupakan objek utama psikologis sastra sebab semata-mata dalam diri manusia itulah aspek kejiwaan yang dapat diekspresikan.

$$
\text { Psikologi sastra yaitu suatu }
$$
pendekatan yang mempertimbangkan segisegi kejiwaan dan menyangkut batiniah manusia. Lewat pendekatan psikologi ini akan nampak bahwa fungsi dan peranan sastra ialah untuk memancarkan bahwa karya satra pada bertujuan untuk melukiskan kehisupan manusia. Psikoanalisis yaitu cabang ilmu yang dikembangkan oleh sigmund freud dan para pengikutnya. 


\subsection{Keterkaitan antara psikologi dengan} sastra

Psikologi sastra adalah kajian sastra yang memandang karya sastra sebagai aktivitas kejiwaan, pengarang akan mengunakan cipta, rasa dan karsa dalam berkaya. Begitupula pembaca, dalam menanggapi karya juga tidak lepas dari kejiwaan masing-masing.

Unsur psikologis adalah unsur cerita yang mampu memberikan makna tersendiri bagi pembacanya melalui suasana hati, jalan pikiran seseorang, dan unsur psikologis didalam karya sastra sangat berkaitan erat dengan jalan pikiran pembaca dalam menanggapi suatu peristiwa tertentu

\subsection{Tipe-Tipe Watak Manusia Menurut} William Schutz

Menurut Schutz secara psikis orang mengalami tiga kebutuhan antarpribadi yaitu:

- Tipe Ketermasukan (Inclusion)

Pada kebutuhan ketermasukan inklusi interaksi sosial yang dapat dilakukan seseorang ada tiga derajat atau tingkatan ketermasukan, yaitu tipe hipersosial atau oversocial adalah orang yang banyak bergaul dengan orang lain dan bersifat ekstrovert. Tipe hipososial atau undersocial orang dengan tipe ini tidak suka mencari teman, selain itu mudah mengeluh, membutuhkan privacy. Dan ada juga yang berbentuk tipe social orang dengan tipe ini, ia menghargai privacy dan company, ia tidak mempunyai problem batin.

- Tipe Kekuasaan (Control)

Menurut William C. Schutz (dikutip dalam Rakhmat, 2007:168) pada kebutuhan kekuasaan control ada tiga derajat atau tingkatan yang menyangkut kekuasaan itu, yaitu tipe autokrat adalah tipe orang yang berkuasa, berpengaruh, menguasai orang lain, dan mengatur hidupnya.

- Tipe Keafektifan (Affection)

\section{HASIL PENELITIAN DAN PEMBAHASAN}

3.1 Sinopsis Cerita Novel Sebening Senja Karya Nawank Wulan

Kisah yang tertuang dalam novel ini adalah mengenai perjalanan hidup seorang gadis yang lahir dan dibesarkan dilingkungan keluarga yang penuh misteri. Senja Larasati gadis berhijab, soleha, pintar dan religius, namun dibalik kesempurnaan itu tersimpan segumpal tanda tanya dalam hatinya karena sejak kecil hingga menginjak kelas I SMA tidak pernah merasakan kasih sayang utuh dari mamanya. Sinis, ketus, dan dingin yang selalu ditunjukkan oleh mamanya dan berbeda jauh dari yang dialami oleh Mela Larasati kakak perempuannya. Papa Senja telah meninggal sejak dia kecil, sehingga hanya Mela yang selalu menjadi penyejuk saat dia haus akan kasih sayang mama. 
Hidup ini memang penuh dengan misteri ada banyak hal yang belum terpecahkan semua hanya membutuhkan satu hal. Kesabaran dengan kesabaran Tuhan akan membukakan seribu kemenangan. Karena Ia tak salah dalam memberikan ujian. Tuhan telah menakar kemempuan kita hanya orang terpilihlah yang banyak menerima ujiandari Nya.Senja cukup bahagia bisa mengenal Fandy, dia Cuma bisa berkata terima kasih atas segala perhatian dan kasih sayangnya selama ini. Terima kasih pula atas cinta yang kau beri bukan maksud memungkiri hati ini atau pun menyakiti, justru Senja tak ingin banyak orang yang tersakiti Senja tak bisa menjadi embun di saat pagi datan Senja tak bisa menjadi angin yang menerbangkan awan seperti yang kau inginkan Senja hanya bisa diam.

Namun kebencian mamanya seolah berubah dengan rasa sayang, ketika Senja merelakan satu ginjalnya utuk Mela.Mela mengidap gagal ginjal dan mengharuskannya mendapatkan donor ginjal.Tanpa sepengetahuan Mela dan mamanya, Senja diam-diam menjadi pendonor ginjal untuk Mela. Namun hal tersebut diketahui oleh Mela dan mamanya, saat itulah mamanya menyadari bahwa Senja bukanlah anak yang jahat dan Senja memiliki hati yang sangat bersih hingga membuat mama Senja sadar akan kesalahannya selama ini. Mela pun sangat bahagia menjadi kakak Senja serta menyadari bahwa Senjalah yang selama ini dicintai oleh Fandy.Bukankah cinta itu sebuah keberanian, berani mencintai meski tidak dicintai, berani berkorban meski sering tersakiti dan berani untuk tidak memiliki meski terlalu mencintai.itu yang tertulis dalam diare Senja. Fandy bangga dengan cinta mereka berdua cintanya membuat mereka kuat dan hebat.

\subsection{Analisis Unsur-Unsur Intrinsik Pada}

Novel Sebening Senja Karya Nawank Wulan

Analisis unsur-unsur intrinsik pada novel Sebening senja karya Nawank Wulan MN meliputi: 1) tema; 2) alur 3) latar; 4) penokohan; 5) sudut pandang; 6) amanat; dan 7) gaya bahasa.

\section{Tema}

Berdasarkan uraian diatas dapat disimpulkan tema dalam Sebening Senja karya Nawank Wulan adalah cinta terhadap Mama yang sangat besar.

\section{Alur}

Alur yang terdapat dalam novel Sebening Senja karya Nawank Wulan adalah menggunakan alur campuran karena peristiwa diceritakan dengan alur maju dan alur mundur pada akhirnya berakhir dengan penyelesaian yang menyedihkan. 


\section{Latar}

Berdasarkan uraian diatas dapat disimpulkan tempat kejadian atau peristiwa yang terjadi adalah di dalam ruangan.

\section{Penokohan}

\section{1) Senja Larasati}

Tokoh Senja gadis manis, berhijab, soleha, pintar dan religius. Tentang keadaan Senja tersebut dapat diketahui dalam bentuk cakapan atau dialog pada kutipan berikut.

“Adikmu manis juga.Lucu, pakai jilbab. Siapa namanya Mel?," yanya lagi sambil mengangguk kecil ke arahku. Aku melihatnya dari kaca spion (Wulan, 2013:6).

\section{2) Tokoh Mama/ Laras (Tokoh Kedua)}

"Mengapa Mama terlalu dingin dan kaku padaku. Dan secuil pun tak pernah paham, mengapa tak pernah sekalipun kudengar Mama memarahi Kak Mela. Aku selalu berusaha untuk positif thingking akan hal ini, namun terkadang pikiran kacau itu menyesaki tiap sudut nalarku" (Wulan, 2013:3).

\section{3)Tokoh Mela}

"kata kak Mela lagi, dan lagi.Selalu menjadi pembelaku setiap hari, terkadang aku malu.Malu pada diriku sendiri terlebih pada kak mela. Entah mengapa aku merasa dunia seolah mencibirku, tak tahu lagi apa yang harus kulakukan untuk memperbaiki semuanya. Entah! (Wulan, 2013:3).

\section{4)Tokoh Fandy Pratama}

"Ya jelas bedalah. Dia kan si misterius. Cowok teraneh dan terajaib sepanjang sejarah Trisakti” (Wulan, 2013:9).

Dulu dia penyayang nahkan gak pernah sekalipun ngebentak gue, suka bercanda, usil, pintar dan jago main basket tapi semua berubah karena..." (Wulan, 2013:16).

\section{5) Tokoh Tyas Sintiadewi}

Pengarang menggambarkan Tyas di dalam novel ini sebagai seorang perempuan yang baik, pintar, supel, agak tomboy dan humoris.Hal tersebut dapat terlihat dalam percakapan berikut.

\section{6)Tokoh Om Rachman}

"Om Rachman adalah adik semata wayang almarhum papa.Dia tinggal di Solo dengan tante Widia dan dua buah hati mereka.Tiara dan Winda.Om Rachman sangat baik padaku.Dia tak pernah membedakan antara aku dengan kak Mela.Tidak seperti mama yang seolah terlalu mengutamakan kak Mela dan memasabodohkan aku" (Wulan, 2013:32).

\section{7) Tokoh Dimas (Tokoh Ketujuh)}

Dimas merupakan teman dari Mela namun Dimas kasihan terhadap 
ketidakadilan mama Mela terhadap Senja oleh karena itu

\subsection{Watak Tokoh-Tokoh Novel Sebening} Senja Karya Nawank Wulan

\section{a. ) Tokoh Senja (tokoh Protagonis)}

Tokoh protagonis adalah tokoh utama yang berwatak baik. Senja gadis manis, berhijab, soleha, pintar dan religius. Tentang keadaan Senja tersebut dapat diketahui dalam bentuk cakapan atau dialog pada kutipan berikut.

"Adikmu manis juga.Lucu, pakai jilbab. Siapa namanya Mel?," yanya lagi sambil mengangguk kecil ke arahku. Aku melihatnya dari kaca spion (Wulan, 2013:6).

\section{b.) Tokoh Mama/ Laras (tokoh antagonis)}

Laras adalah seorang ibu yang mempunyai dua anak perempuan yaitu Senja larasati dan Mela larasati. Laras pada dasarnya merupakan seorang ibu seperti orang tua pada umumnya yang sangat menyayangi putrinya. Tentang keadaan tersebut dapat diketahui dalam bentuk cakapan atau dialog pada kutipan berikut.

$\mathrm{Aku}$ selalu berusaha untuk positif thingking akan hal ini, namun terkadang pikiran kacau itu menyesaki tiap sudut nalarku" (Wulan, 2013:3).

\section{c. Tokoh Pembantu}

1) Tokoh Mela (Tokoh Ketiga)
Mela adalah tokoh ketiga dalam novel Sebening Senja karya Nawank Wulan.Mela merupakan putri pertama dari Laras dan merupakan kakak perempuan Senja.

"kata kak Mela lagi, dan lagi.Selalu menjadi pembelaku setiap hari, terkadang aku malu.Malu pada diriku sendiri terlebih pada kak mela. Entah mengapa aku merasa dunia seolah mencibirku, tak tahu lagi apa yang harus kulakukan untuk memperbaiki semuanya. Entah! (Wulan, 2013:3).

\section{2)Tokoh Fandy Pratama (Tokoh}

\section{Keempat)}

Fandy adalah tokoh keempat dalam novel Sebening Senja karya Nawank Wulan ini.

"Ya jelas bedalah. Dia kan si misterius. Cowok teraneh dan terajaib sepanjang sejarah Trisakti” (Wulan, 2013:9).

\section{3) Tokoh Tyas Sintiadewi (Tokoh} Kelima)

Tyas adalah tokoh kelima dalam novel Sebening Senja karya Nawank Wulan.Tyas merupakan sahabat terbaik Senja dan juga adik Fandy.Pengarang menggambarkan Tyas di dalam novel ini sebagai seorang perempuan yang baik, pintar, supel, agak tomboy dan humoris.Hal 
tersebut dapat terlihat dalam percakapan berikut.

“... Dia adalah sahabat baruku di SMA Trisakti.Anak yang baik, pintar, supel, agak tomboy dan humoris.Yah bahkan sangat humoris menurutku.Ia selalu membuatku tertawa disetiap ceritanya. Ada saja hal lucu dan konyol yang ia ceritakan" (Wulan, 2013:10)

\section{4) Tokoh Om Rachman (Tokoh Keenam)}

Tokoh Rachman adalah tokoh keenam dalam novel Sebening Senja karya Nawank Wulan. Om Rachman adalah adik semata wayang almarhum papa Senja, om Rachman sangat menyayangi Senja dan tidak pernah membedakan kasih sayangnya antara Senja dan Mela. Hal tersebut dapat terlihat dalam percakapan berikut.

\section{5)Tokoh Dimas (Tokoh Ketujuh)}

Dimas merupakan teman dari Mela namun Dimas kasihan terhadap ketidakadilan mama Mela terhadap Senja oleh karena itu Dimas berusaha membantu Senja untuk kebahagiaannya.

\subsection{Analisis Watak Tokoh-Tokoh Novel} Sebening Senja Karya Nawank Wulan

\section{Berdasarkan Kajian Psikologis}

\section{a. Tokoh Utama}

Berikut ini watak tokoh dan penokohan menurut teori William C. Schutz dalam hubungan antar personal yaitu novelSebening Senja karya Nawank Wulan.

\section{- Tipe ketermasukan (inclusion)}

Tokoh Senja ditinjau dari kebutuhan ketermasukan adalah orang berwatak tipe social'

"Senja!" panggilan kak Mela menghentikan obrolanku dengan Tyas, teman baruku.Aku menoleh sembari melambaikan telapak tanganku kea rah mereka.Kak Mela, kak Mike dan kak Hessel, mereka kompak mengacungkan jempol (Wulan, 2013:8).

Tokoh Mama, ditinjau dari kebutuhan ketermasukan (inclusion) adalah orang berwatak tipe hipososial karena Mama menginginkan Senja menjauhi Fandy untuk Mela.

"Bagus deh.Jangan sampai kamu menyakiti hati kakakmu.Dia selalu mengalah demi kamu selama ini. Mama gak rela". (Wulan, 2013:37).

\section{- Tipe kekuasaan(Control)}

Tokoh Senja, ditinjau dari kebutuhan kekuasaan (control) adalah orang berwatak tipe abdikrat karena Senja sulit untuk menghilangkan rasa kasih dan cintanya kepada Fandy walaupun dia telah berusaha keras mengikhlaskannya untuk kakaknya. Watak tipe abdikrat tokoh Senja dideskripsikan oleh pengarang dengan teknik analitik pada kutipan di bawah ini. 
Watak tipe abdikrat tokoh Mama dideskripsikan oleh pengarang dengan teknik analitik pada kutipan di bawah ini.

"Biar saja dia tahu yang sebenarnya Man. Aku sudah capek menyembunyikan semuanya selama 16 tahun ini. Biar saja dia tahu kalau dia bukan darah dagingku dan Mas Rahmat. Biar saja dia tahu kalau mas Rahmat menemukannya tergeletak di depan kantor kami 16 tahun silam dan karena dia juga akhirnya mas Rahmat kecelakaan. (Wulan, 2013:153).

\section{- Tipe keafektifan(Affection)}

Berdasarkan kebutuhan keafektifan (affection), tokoh Senja adalah orang berwatak tipe hiperpersonal karena Senja merupakan tokoh yang tidak suka melihat orang yang dicintainya menderita dan bersedih.Watak tipe hiperspersonal tokoh Senja dideskripsikan oleh pengarang dengan teknik analitik pada kutipan berikut.

Tapi kasihan kak Mela, Yas.Kakakmu itu emang benar-benar orang teraneh sedunia.Lihat saja.Mungkin dalam hatinya, kak Mela hanya dianggap seperti burung beo. Huh" dengan cepat, kutarik tangan kak Mela (Wulan, 2013:19)

\section{b. Tokoh Pembantu}

\section{1) Tokoh Mela (Tokoh Ketiga)}

Tokoh Mela ditinjau dari kebutuhan ketermasukan (inclusion) adalah orang berwatak tipe hipersosial, karena Mela tidak suka melihat Senja selalu bersedih

“... Sedangkan kak Mela hanya dan selalu berusaha menghiburku ketika Kristalkristal bening mulai menggantung di kedua sudut mataku (Wulan, 2013:4).

\section{2) Tokoh Fandy (Tokoh Keempat)}

Tokoh Fandy ditinjau dari kebutuhan ketermasukan adalah orang berwatak tipe hipersosial karena Fandy tidak ingin melihat Senja bersedih dan menderita sehingga dia rela mengorbankan perasaannya untuk menerima cinta Mela.

"Hari ini aku menggadaikan hatiku.Entah kapan aku mampu menebusnya kembali. Mungkin hanya Tuhan dan waktu yang akan mebantuku untuk ini. Cinta.Cinta yang selama ini kukejar dan kucari memang telah aku dapatkan namun jarak yang harus memisahkan. Bahkan sangat rela melakukannya karena aku tak bisa melihatnya terluka.Itu saja" (Wulan, 2013:129).

\section{3) Tokoh Tyas (Tokoh Kelima)}

Tokoh Tyas ditinjau dari kebutuhan ketermasukan adalah orang yang berwatak tipe hipersosial karena Tyas tidak ingin melihat Senja bersedih serta tidak ingin melihat Senja dan kakaknya berpisah. Watak tipe hipersosial tokoh Tyas dideskipsikan oleh pengarang dengan teknik analitik pada kutipan di bawah ini. 
"Gue tahu Ja.Karena gue sahabat lo. Gue tahu lo suka sama kak Fandy. Dari perhatian lo, dari cara lo ngmong ke dia dan dari usaha lo ngebuat kak Fandy berubah dan nyatanya lo berhasil" (Wulan, 2013:66).

\section{4) Tokoh Om Rachman (Tokoh Keenam)}

Tokoh Om Rachman ditinjau dari kebutuhan ketemasukan (inclusion) adalah orang berwatak tipe hipersosial karena Rachman tidak suka melihat Senja tersiksa dan selalu bersedih. Watak tipe hipersosial tokoh Om Rachman dideskripsikan oleh pengarang dengan teknik analitik pada kutipan di bawah ini.

"Kamu berdoa saja ya, semoga mamamu bisa berubah.Jangan berpikir yang aneh-aneh. Kamu tetap anak mama dan almarhum pap dan kamu juga tetap keponakan om yang paling manis" ucap om Rachman sembari mencubit pipi kiriku. Aku hanya menjawab deretan nasihatnya dengan senyum (Wulan, 2013:33).

\section{5)Tokoh Dimas (Tokoh Ketujuh)}

Tokoh Dimas ditinjau dari kebutuhan ketermasukan adalah orang berwatak tipe hipersosial karena Dimas kasihan terhadap ketidakadilan mama Mela terhadap Senja oleh karena itu Dimas berusaha membantu Senja untuk kebahagiaannya. Hal tersebut dapat terlihat dari percakapan berikut.
"Si Fandy tahu kalau Mela gak ikut kegiatan ini pastinya mama lo juga ngelarang lo untuk ikut.Makanya dia belabelain bujuk si Mela berjam-jam sampai ditraktir makan di kantinya mang Jojon segala" tambah kak Dimas kemudia. Aku hanya mengerutkan alis. Tyas menepuk pundakku pelan" (Wulan, 2013:80).

\subsection{Pembahasan Terhadap Hasil Temuan}

\section{- Tokoh Utama}

Tokoh Senja ditinjau dari kebutuhan ketermasukan adalah orang berwatak tipe social karena Senja cepat berinteraksi dan berkomunikasi dengan sekolah barunya, karena Senja langsung mempunyai sahabat dan orang-orang yang cepat menyayanginya.

Tokoh Mama berdasarkan teori William Schutz memiliki watak tipe hiporsosial pada segi kebutuhan ketermasukan atau inclusion; watak tipe abdikrat pada segi kebutuhan kekuasaan atau control. Hal ini tergambar dari sikap Mama yang suka ketus, jahat, dan menghina Senja sihingga selalu membuat Senja tersiksa dan sedih.

\section{b. Tokoh Pembantu}

Tokoh Mela berdasarkan teori William Schutz memiliki watak tipe hipersosial pada segi kebutuhan ketermasukan; watak autokrat pada segi kebutuhan kekuasaan; dan watak tipe hipersonal pada segi kebutuhan 
keafektifan.Hal ini tergambar dari sifat Mela yang selalu menjadi pembela dan pelindung saat Senja bersedih ataupun mendapat perlakuan tidak baik dari mamanya.kutipan berikut.

Tokoh Fandy berdasarkan teori William Schutz memiliki watak tipe hipersosial pada segi kebutuhan ketermasukan; watak autokrat pada segi kebutuhan kekuasaan; dan watak hipersonal pada segi kebutuhan keafektifan. Hal ini tergambar dari sikap Fandy yang sangat mencintai Senja dan merelakan perasaannya untuk Mela demi kebaikan Senja.

Tokoh Dimas berdasarkan teori William Schutz memiliki watak tipe hipersosial pada segi kebutuhan ketermasukan; Hal tersebut tergambar dari sikap Dimas yang merasa kasihan atas nasib Senja.Dimas merupakan teman dari Mela namun Dimas kasihan terhadap ketidakadilan mama Mela terhadap Senja oleh karena itu Dimas berusaha membantu Senja untuk kebahagiaannya.

\section{SIMPULAN, IMPLIKASI, DAN}

\section{SARAN}

\subsection{Simpulan}

Tokoh Senja berdasarkan teori William Schutz memiliki watak tipe sosial dan hipersosial pada segi kebutuhan ketermasukan atau inclusion; watak tipe autokrat pada segi kebutuhan kekuasaan atau control; dan berwatak tipe hipersonal pada segi kebutuhan keafektifan atau affection.Tokoh Mela berdasarkan teori William Schutz memiliki watak tipe hipersosial pada segi kebutuhan ketermasukan; watak autokrat pada segi kebutuhan kekuasaan; dan watak tipe hipersonal pada segi kebutuhan keafektifan.Hal ini tergambar dari sifat Mela yang selalu menjadi pembela dan pelindung saat Senja bersedih ataupun mendapat perlakuan tidak baik dari mamanya.

\subsection{Implikasi}

Penelitian mengenai psikoanalisis dalam karya sastra yang dilakukan oleh peneliti terdahulu diantaranya"watak tokohtokoh dalam novel burung-burung Rantau Y.B Magunwijaya”, suatu kajian psikosnalisis dalam penelitian ini Darmawati Siregar Mahasiswa Pascasarjana Universitas Sriwijaya Palembang menganalisis tokoh-tokoh berdasarkan teori William C Schutz tentang terbentuknya watak manusia yang bermacam tipe. Hasil tesis nya didapati watak-watak tokoh, watak yang mendominasi tokoh-tokoh dalam novel Burung-burung Rantau karya Y.B Magunwijaya ialah tipe sosial. Tokoh-tokoh yang ada pada novel tersebut umumnya berwatak tidak normal, berwatak ganda 
bahkan berwatak banyak karena tokoh-tokoh tersebut memiliki konflik batin.

sedangkan perbedaan penelitian yang kedua dengan penelitian yang peneliti lakukan terletak pada sumber data dan kajiannya. Pada penelitian yang kedua ini sumber data yang dikaji oleh Wardah adalah novel Kuhapus Namamu dengan Namanya karya Taufiqurrahman Al-Azizy dengan watak hipersonaldan bentuk kajiannya psikoanalisis.

Sedangkan peneliti yaitu novel Sebening Senja karya Nawank Wulan dan bentuk kajiannya adalah analisis Watak Tokoh dalam Novel Sebening Senja Karya Nawank Wulan Kajian psikologis persamaannya terletak pada kajian psikologis di dalam novel yaitu hubungan timbal balik antara manusia dalam masyarakat dan aspek kejiwaan yang terkandung dalam suatu karya sastra.

\section{- Saran}

Berdasarkan dari kesimpulan di
atas, maka para orang tua yang
menginginkan anaknya berwatak baik dan
dapat berinteraksi dengan masyarakat
sekitar, kekuasaan dan keafektifan haruslah
memilih sikap yang ideal, juga sikap jangan
berat sebelah atas kasih sayang yang
diberikan kepada anak. Karena tidak baik

untuk pertumbuhan sang anak kedepannya. pendidikan sebaiknya dibekali pengetahuan tentang teori terbentuknya watak-watak manusia supaya hasil didikannya terhadap anak didik memiliki watak-watak yang baik dan ideal. Secara teoretis, bagi peneliti sastra atau mahasiswa yang ingin meneliti lebih mendalam dalam kajian dan pendekatan serta objek berbeda di bidang sastra, hasil penelitian ini diharapkan dapat dijadikan masukan, khususnya mengenai teori-teori tentang nilai-nilai novel dengan metode analisis isi, metode deskriptip dan lain sebagainya.

\section{DAFTAR PUSTAKA}

Aminuddin.2009. Pengantar Apresiasi Karya sastra. Bandung:SinarBaru.

Endraswara, Suwardi. 2013. Teori Kritik Sastra. Yogyakarta: CAPS.

Jabrohim,(Ed) (2003) Metodologi Penelitian Sastra. Yogyakarta: Hanindita

Kartono, kartini. . Psikologi Umum. Bandung: Mandar Maju.

Kosasih. 2012. Dasar-Dasar Keterampilan Bersastra. Bandung: Yrama Widya.

Mursidin. 2010. Psikologi Umum. Bandung: CV Pustaka Setia.

Nurgiyantoro. 2009. Teori pengkajian Fiksi. Yogyakarta: Gajah Mada University perss. 
Nurgiyantoro.2012 University perss.Teori pengkajian Fiksi. Yogyakarta: Gajah Mada

Pradopo, Rachmat Djoko. 2000. Pengkajian

Puisi. Yogyakarta: Gadjah Mada

University Press.

Rakhmat, Jalaludin. 2007. Psikologi Komunikasi. Bandung: Remaja Rosdakarya

Ratna, Nyoman kutha. 2013. Teori, Metode, dan teknik Penelitian Sastra. Yogyakarta: Pustaka Pelajar.

Sayuti, Suminto A. 2007. Puisi dan

Pengajarannya. Semarang: IKIP Press.

Semi, M. Atar. 2003. Metode Penelitian Sastra. Bandung: Angkasa.

Siswantoro, 2005. Metode Penelitian Sastra: Analisis Psikologis. Surakarta: Muhammadyah University Press.
Soetarno. 2008. Bahasa dan Sastra Indonesia. Surakarta: Widya Duta.

Suharianto, S. 1992. Dasar-Dasar Teori Sastra. Surakarta: Widya Duta.

Sudaryat, Ndang. 2001. Ringkasan Bahasa Indonesia. Bandung: Ganeca Exact Suryabrata, Sumadi. 2013. Psikologi Kepribadian. Jakarta: Rajawali Pers.

Susanto, Dwi. 2011. Pengantar Teori Sastra. Yogyakarta: CAPS.

Verhaar, John. M.V. 1989. Manusia Menurut Psikologi dan Psikiater Abad ke-20. Yogyakarta: Kanisius.

Walgito. 2003. Psikologi Sosial. Jogjakarta: Andi Jogjakarta. 